\title{
Catalytic Technologies for the Production of Eco-friendly Gasolines and Reducing the Toxicity of Vehicle Exhaust Gases
}

\section{ALMA MASSENOVA*, MAXAT KALYKBERDIYEV, ABZAL USSENOV, ALEXANDR SASS, NAIL KENZIN, ERLAN KANATBAYEV and AMANKELDI BAIKEN}

\author{
JSC «D. V. Sokolskii Institute of Fuel, Catalysis and Electrochemistry», Almaty, Kazakhstan. \\ ${ }^{*}$ Corresponding author E-mail: almasenova@mail.ru \\ http://dx.doi.org/10.13005/ojc/350143
}

Received: October 20, 2018; Accepted: December 07, 2018)

\begin{abstract}
The work is devoted to the catalytic hydrodearomatization of gasoline fractions to reduce the content of benzene and polycyclic aromatic hydrocarbons and the catalytic oxidation of carbon monoxide in motor vehicle exhaust gases. At hydrodearomatization of gasoline fractions of LLP "Atyrau Refinery" on $0.2 \% \mathrm{Rh}-\mathrm{Pt} / \mathrm{Al}_{2} \mathrm{O}_{3}$ bimetallic catalyst, the benzene content of the stable catalysate $\mathrm{LG}$ fraction decreased from 3.23 to $0-0.03 \%$ and the content of aromatic hydrocarbons decreased from 55.04 to $28.40 \%$ and benzene was completely removed of the fraction Straight-run gasoline AVT with the decrease of aromatic hydrocarbons from 9.93 to $5.04 \%$. CO oxidation with $100 \%$ conversion over metal block Pt-Co/ $\mathrm{Al}_{2} \mathrm{O}_{3}$ catalysts begins already at $100^{\circ} \mathrm{C}$, the optimal volume rate for the oxidative conversion of $\mathrm{CO}$ is $80000-100000 \mathrm{~h}^{-1}$. Tests on a pilot plant showed complete removal of monoxide from the exhaust gases of internal combustion engine.
\end{abstract}

Keywords: Benzene, Aromatic hydrocarbons, Hydrodearomatization, Oxidation, Carbon oxide, Exhaust gases.

\section{INTRODUCTION}

Motor transport is one of the largest air pollutants. The problem of exhaust gases purification of motor vehicles is one of the most important problems of humanity, attracting the attention of the public and scientists of the leading countries of the world. The cause of pollution is the low quality of fuels, which produce toxic substances in the exhaust gases during combustion. The composition and quantity of toxic exhaust gases depends on the quality of fuels. In Kazakhstan, about 3 million tons of harmful substances, such as carbon monoxide, hydrocarbons, oxides of sulfur and nitrogen etc. are emitted daily into the atmosphere. ${ }^{1}$ The level of air pollution in many industrial cities of Kazakhstan exceeds more than ${ }^{6-10}$ times the existing standard limits due to emissions from motor vehicles, boilers and factories. This problem is acute for many industrial cities of the world.

The quality of fuels largely depends on the hydrocarbon composition. Monoaromatic compounds present aromatic hydrocarbons in fuels: benzene, toluene, xylene isomers and polyaromatic: naphthalene, tetralin and other condensed aromatic

This is an Open Access article licensed under a Creative Commons license: Attribution 4.0 International (CC- BY). Published by Oriental Scientific Publishing Company @ 2018

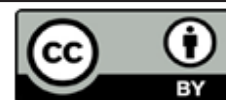


compounds. The product of incomplete combustion of benzene is benzpyrene - a strong carcinogen. During burning of 1 liter of gasoline, $81 \mu \mathrm{g}$ benzpyrene is produced in the exhaust gases and in case of liter of diesel fuel - up to $170 \mu \mathrm{g}$. High carcinogenicity of benzene makes it necessary to limit its concentration in the composition of gasolines. According to the standards of gasoline EURO-5,6, the content of benzene must be less than $0.1 \%$ and aromatic hydrocarbons $11-30 \%$. During the operation of low-quality fuels and oils in addition to harmful emissions into the atmosphere there is a rapid wear of machinery parts due to carbon deposition from polycyclic aromatic hydrocarbons the service life of machinery decreases by $30 \%$. Reducing the amount of aromatic hydrocarbons in automotive fuels will extend the service life of machines.

Decrease in the proportion of aromatic hydrocarbons in oils and petroleum products can be achieved by various methods, one of the main catalytic processes is hydrodearomatization of gasoline fractions in the presence of highly efficient catalysts, in which process the operational characteristics of petroleum fuels, oils and raw materials for petrochemical refining are improved..$^{2-3}$

Scientists from many countries are engaged in the problem of hydrodearomatization of oil products - USA, Great Britain, France, Germany, Japan, Russia, China, Poland etc. ${ }^{4-18}$ The main development trends in the field of hydrodearomatization of automotive fuels and the development of catalysts based on platinum metals are aimed to reducing the cost of catalysts (decrease of the content of noble metal, selection of carriers and modifiers) and increasing their stability and resistance to sulfur compounds. In addition, hydrogenation processes are carried out on metal oxide catalysts, where $\mathrm{Co}, \mathrm{Mo}, \mathrm{Ni}, \mathrm{Cu}, \mathrm{W}$ and other transition metals are used as the metal. The most effective and selective catalysts for hydro-dehydrogenation reactions are catalytic systems based on platinum group metals, primarily $\mathrm{Pt}, \mathrm{Pd}, \mathrm{Rh}$ and $\mathrm{Ru}$. By varying the nature of the carrier and modifier uniform distribution of metals in the pores, optimal acidity and stability against sulfur-containing compounds have been achieved. In literature of the last years on catalysis, there is significant interest in the process of hydrogenation of aromatic hydrocarbons, which largely explains the practical use in the production of environmentally friendly fuels. In refinery industry both catalysts based on metals of group VIII and sulphide are used, but in the case of latter benzene and aromatic hydrocarbons are hydrogenated under more severe conditions.

When burning in the cylinders of an internal combustion engine of one ton of fuel, the amount of emitted carbon monoxide into the atmosphere is from 150 to $800 \mathrm{~kg}$, depending on the mode of operation, type of engine and its adjustment. One of the most effective ways of utilization and neutralization of harmful exhausts of motor transport is the catalytic oxidation of toxic components to carbon dioxide and water. ${ }^{2}$

Modern catalysts for the neutralization of harmful impurities in industrial gas emissions can be divided into three main groups: containing noble metals; consisting of transition metal oxides; mixed catalysts including oxides of d-elements and platinum group metals. But the catalysts with noble metals remain the most active and are widely used for industrial purification of waste gases, despite the high cost of platinum metals.

The actual task is to replace the noble metal catalyst system with cheaper oxide catalysts, in particular oxide catalysts based on transition metals, valencies, which differ in the variety of the composition and the corresponding starting compounds. The question of the nature and interaction of the active components of the catalysts, as well as the mechanism of the catalytic reaction is discussed. The results of numerous studies have shown that catalytic systems based on cobalt have catalytic activity at low temperatures because of its unique activity for the oxidation of $\mathrm{CO}^{19}$. Investigation of the effect of aluminum oxide on the $\mathrm{Co}_{3} \mathrm{O}_{4} / \gamma-\mathrm{Al}_{2} \mathrm{O}_{3}$ catalyst ${ }^{20-21}$ of various synthesis methods have shown that the catalyst obtained by the impregnation methods has a high activity. It was shown by XRPD method that $\mathrm{CoAl}_{2} \mathrm{O}_{4}, \mathrm{Co}_{3} \mathrm{O}_{4}, \mathrm{Co}$ and $\mathrm{Al}_{2} \mathrm{O}_{3}$ phase are present in $\mathrm{Co} / \mathrm{Al}_{2} \mathrm{O}_{3}$ catalysts depending on the Co content. ${ }^{18-19}$ The catalysts obtained by the combination of noble metals, in particular Pt and Co oxides, have shown high activity in $\mathrm{CO}$ oxidation..$^{23-24}$

The present work is devoted to topical aspects of environmental catalysis: study of the catalytic hydrodearomatization of gasoline fractions of LLP "Atyrau Refinery" to improve the quality of Kazakhstan gasoline by reducing the benzene 
content in them and removing carbon monoxide in exhaust gases by catalytic oxidation to carbon dioxide.

\section{MATERIALS AND METHODS}

The materials used are $\mathrm{H}_{2} \mathrm{PtCl}_{6} .6 \mathrm{H}_{2} \mathrm{O}$ (TU 2612-034-00205067-2003, Russia), $\mathrm{RhCl}_{3} \cdot 3 \mathrm{H}_{2} \mathrm{O}$ (MRTU 609 1833-64), $\mathrm{Co}\left(\mathrm{NO}_{3}\right)_{2} \cdot 6 \mathrm{H}_{2} \mathrm{O}$ (GOST 452878). Pseudoboehmite is used to produce $\gamma-\mathrm{Al}_{2} \mathrm{O}_{3}$ (SKBT LLC, Russia).

Catalysts were investigated by electronic microscopy measurement (TEM and SEM), thermoprogrammed reduction (TPR) on «ChromatechCrystall5000" (catharometer). XRD was carried out on the diffractometer DRON-4-07 with Co-Ka radiation, Russia. Analysis of the initial substances and reaction products was carried out by gas chromatography «Chromatech-Crystall 2000M» (FID), Russia.

\section{EXPERIMENTAL}

\section{Catalyst Preparation}

The $\gamma-\mathrm{Al}_{2} \mathrm{O}_{3}$ support for two types of catalysts was prepared from pseudoboehmite by calcination at $650^{\circ} \mathrm{C}$ for 2 hours. Specific surface area of the aluminum oxide was $170 \mathrm{~m}^{2} / \mathrm{g}$. Catalysts for hydrogenation are prepared by impregnation method on moisture capacity with a small excess of water of aluminum oxide with solutions of $\mathrm{H}_{2} \mathrm{PtCl}_{6} \cdot 6 \mathrm{H}_{2} \mathrm{O}$ and $\mathrm{RhCl}_{3} \cdot 3 \mathrm{H}_{2} \mathrm{O}$ with further reduction by hydrogen at $250^{\circ} \mathrm{C}$ for 4 hour.

The oxidation catalysts are model systems of the catalytic phase applied to the basis - metal block installed in automobile catalytic converters. The $\gamma-\mathrm{Al}_{2} \mathrm{O}_{3}$ support was prepared from pseudoboehmite by calcination at $650^{\circ} \mathrm{C}$ for 2 hours. The oxidation catalysts were prepared by impregnation method on moisture capacity with a small excess of water of aluminum oxide with solutions of $\mathrm{Co}\left(\mathrm{NO}_{3}\right)_{2} \cdot 6 \mathrm{H}_{2} \mathrm{O}$ or $\mathrm{H}_{2} \mathrm{PtCl}_{6} \cdot 6 \mathrm{H}_{2} \mathrm{O}+\mathrm{Co}\left(\mathrm{NO}_{3}\right)_{2} \cdot 6 \mathrm{H}_{2} \mathrm{O}$ with further calcination at $300-1100^{\circ} \mathrm{C}$ for 1 hour in air. The cobalt content in the catalysts is $10 \%, 15 \%$ and $20 \%$, content of $\mathrm{Pt}$ is $0.5 \%$.

The work consists of two sections: catalytic hydrodearomatization of gasoline fractions to reduce the content of benzene and polycyclic aromatic hydrocarbons and the neutralization of carbon monoxide from vehicle exhaust gases.
Testing of catalysts in the process of hydrodearomatization was carried out in an autoclave - an apparatus for carrying out hydrogenation processes during heating and under pressure above atmospheric by the firm Amar Equipment Ltd (India). Catalysts for $\mathrm{CO}$ oxidation were investigated in a flow-through catalytic installation with a tubular reactor of the integral type Finetec-4100 (China). In the experiments, the hydrogen pressure, temperature, and space velocity were varied.

\section{RESULTS AND DISCUSSION}

\section{Hydrodearomatization of benzene fractions}

Two gasoline fractions of LLP "Atyrau Refinery" were subjected to hydrogenation: Straightrun gasoline AVT ( $0.37 \%$ benzene) and Stable catalysate LG (3.23\% benzene). Bimetallic catalysts $\mathrm{Pt}-\mathrm{Rh} / \mathrm{Al}_{2} \mathrm{O}_{3}$ were used as catalyst, which showed the best results in the hydrogenation of benzene $100 \%$ conversion and $100 \%$ yield of cyclohexane in previous research. ${ }^{25}$

Three Rh-Pt(8:2)/ $/ \mathrm{Al}_{2} \mathrm{O}_{3}$ catalysts were tested with different content of the active phase: $0.2,0.5$ and $1.0 \%$. Fig. 1 presents data on the hydrodearomatization of the Stable catalysate LG fraction. The reduction of benzene content proceeds from 3.23 to 0.11 on $0.2 \%$ of the catalyst, and over catalysts with $0.5,1.0 \%$ benzene is absent. Reducing the amount of aromatic hydrocarbons from $55.04 \%$ in the original gasoline to $28.4 \%$. The best catalyst is $0.2 \% \mathrm{Rh}-\mathrm{Pt}(8: 2) / \mathrm{Al}_{2} \mathrm{O}_{3}$.

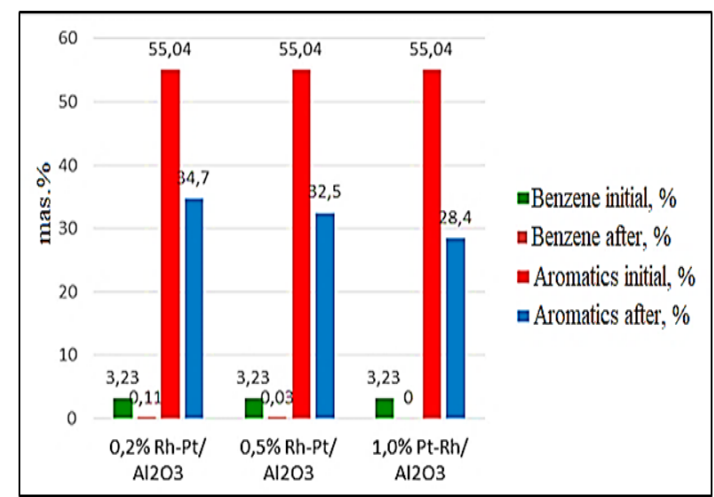

Fig. 1. Hydrogenation of fractions of Stable catalysate LG on $0.2 \% \mathrm{Rh}-\mathrm{Pt} / \mathrm{Al}_{2} \mathrm{O}_{3}, 0.5 \% \mathrm{Rh}-\mathrm{Pt} / \mathrm{Al}_{2} \mathrm{O}_{3}$ and $1.0 \% \mathrm{Rh}-\mathrm{Pt} / \mathrm{Al}_{2} \mathrm{O}_{3}$ catalysts at $50^{\circ} \mathrm{C}$ and $4.0 \mathrm{MPa}$

Pilot tests on hydrodearomatization of two gasoline fractions were carried out on the best 
catalyst. Fig. 2 presents data on the group composition of the initial and after hydrodearomatization of the Stable catalysate $\mathrm{LG}$ on $0.2 \% \mathrm{Rh}-\mathrm{Pt} / \mathrm{Al}_{2} \mathrm{O}_{3}$ in a pilot plant at $50^{\circ} \mathrm{C}$ and $4.0 \mathrm{MPa}$.

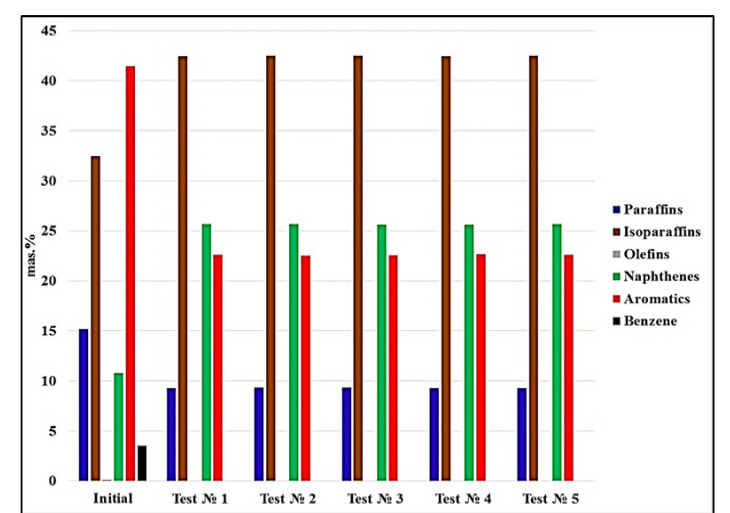

Fig. 2. Group composition of hydrocarbons of Stable catalysate $L G$ before and after the reaction on $0.2 \%$ $\mathrm{Rh}-\mathrm{Pt} / \mathrm{Al}_{2} \mathrm{O}_{3}$ catalyst

The results of 5 experiments are presented, between the data of which there are small discrepancies that fall within the experimental error - $1 \%$. Benzene in all experiments removed by $100 \%$, aromatics content decreased from 41.47 to 22.49 wt.\%. Amount of paraffin hydrocarbons decreased from 15.18 to $9.26 \%$ and amount of isoparaffins increased from 32.47 to 42.49 wt.\% (Figure 2).

Data on the hydrodearomatization of an initial Stable catalysate $L G$ and after the reaction at $0.2 \% \mathrm{Rh}-\mathrm{Pt} / \mathrm{Al}_{2} \mathrm{O}_{3}$ in a pilot plant at $50^{\circ} \mathrm{C}$ and $4.0 \mathrm{MPa}$ were presented in Fig. 3. For Straight-run gasoline AVT benzene in all 5 experiments was removed by $100 \%$, the aromatics amount decreased from 9.93 to $5.03 \mathrm{wt} . \%$. The amount of alkanes decreased from 31.98 to $6.15 \%$, amount of isoparaffins increased from 32.52 to 57.70 wt.\% (Figure 3).

Thus, the pilot tests of the synthesized catalyst showed following results: after the catalytic treatment benzene in gasoline is absent, and the content of aromatic hydrocarbons is almost reduced by half. In addition, the paraffin content decreases with iso-paraffins increase, which indicates that the synthesized catalysts, in addition to hydrogenation, carry out the process of hydroisomerization of normal paraffins to branched iso-paraffins with a high octane number.

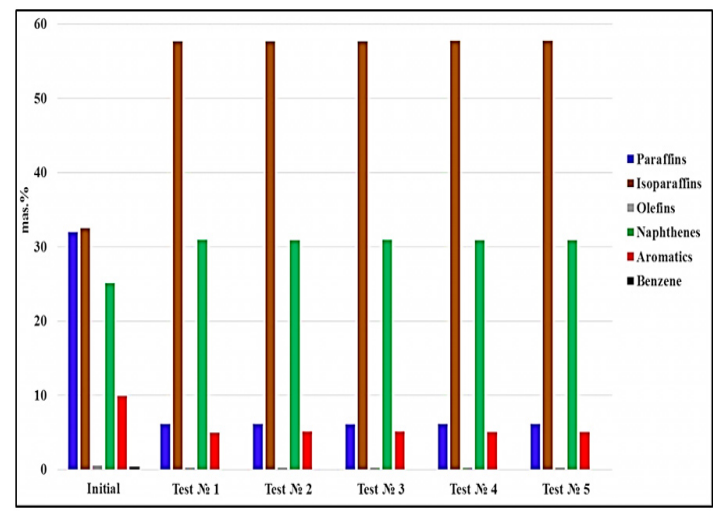

Fig. 3. Group composition of hydrocarbons of Straight-run gasoline AVT before and after the reaction on $0.2 \%$ $\mathrm{Rh}-\mathrm{Pt} / \mathrm{Al}_{2} \mathrm{O}_{3}$ catalyst

Gasoline fractions of Stable catalysate LG and Straight-run gasoline AVT, processed in the course of hydrodearomatization, were investigated for the value of octane number in LLP "Independent Center for Petroleum Products Examination ORGANIC". The data for the analyzes are given in Table 1. Octane number by the Research method (RM) after treatment of the stable catalysate did not change and was equal to 94 units. And octane number by the motor method (MM) increased from 82.6 to 82.7. This suggests that the hydrogenation treatment of gasoline does not reduce octane number.

Table 1: Octane number of gasoline fraction LG

Stable catalyzed and AVT straight-run gasoline before and after catalytic treatment

\begin{tabular}{lcc}
\hline Gasoline & Octane number RM & Octane number MM \\
\hline LG stable catalysate & & \\
Initial (sample 1) & 94 & 82,6 \\
After experiment (sample 2) & 94 & 82,7 \\
Straight-run gasoline AVT & & 50 \\
Initial (sample 1) & 60 & 50 \\
After experiment (sample 2) & 60 & \\
\hline
\end{tabular}

Electron microscopic study of Rh-Pt/Al $\mathrm{O}_{3}$ catalyst has been carried out. Fig. 4 shows images of SEM and TEM microscopy. A uniform distribution of the active metal particles over the catalyst surface is observed, which is well viewed in SEM photograph (Fig. 4, image 1). In the TEM image (Fig. 4, image 2), $0.2 \% \mathrm{Rh}-\mathrm{Pt}(8: 2) / \mathrm{Al}_{2} \mathrm{O}_{3}$ is represented by fine particles 2-2.5 nm in size and a small amount of more dense and large particles $5 \mathrm{~nm}$. Diffuse rings corresponding to $\mathrm{Pt}^{\circ}{ }_{\mathrm{H}} \mathrm{Rh}^{\circ}$ metals represent by microdiffraction patterns of particles. Apparently, the high activity of the catalyst is due to the uniform 
distribution of nanoscale particles on the surface of aluminum oxide.

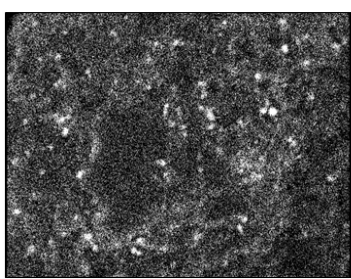

Fig. 4. EM images of Rh-Pt/Al $\mathrm{O}_{3}$. 1 - SEM, 2 - TEM (zoom 160 000)

\section{CO oxidation}

The process of neutralization of carbon monoxide in exhaust gases is aimed in its oxidation to carbon dioxide. During the process of neutralization of carbon monoxide in exhaust gases taken from the internal combustion engine KG-690 of firm "KIPOR", the prepared metal block catalysts were tested. Catalyst testing temperatures ranged from 25 to $500^{\circ} \mathrm{C}$.

The block platinum-cobalt catalyst was tested as the one that showed the most activity in early studies ${ }^{26}$ during the oxidation of carbon monoxide. It was shown that starting from $100^{\circ} \mathrm{C}$, the $\mathrm{CO}$ is completely converted (100\%) and removed from the exhaust gas with a content of $0.036 \mathrm{ppm}$ $\mathrm{CO}$. It has been tested the effect of temperature on carbon monoxide conversion by using this catalyst (Table 2). There is practically no $\mathrm{CO}$ oxidation at $25^{\circ} \mathrm{C}$, this process starts from temperature $100^{\circ} \mathrm{C}$, and at $300^{\circ} \mathrm{C}$ carbon monoxide is completely converted into carbon dioxide.

Table 2: CO oxidation on $10 \% \mathrm{Co}-0.5 \% \mathrm{Pt} /$ $\mathrm{Al}_{2} \mathrm{O}_{3}$ at different temperatures (volume rate $25000 \mathrm{~h}^{-1}$ )

\begin{tabular}{|c|c|c|}
\hline \multirow{2}{*}{$\begin{array}{c}\text { Process } \\
\text { temperature, }{ }^{\circ} \mathrm{C}\end{array}$} & \multicolumn{2}{|c|}{ CO content in exhaust, ppm } \\
\hline & before catalyst & after catalyst \\
\hline 25 & & \\
\hline 0,036 & 0,035 & \\
\hline 100 & & 0,012 \\
\hline 250 & & 0,003 \\
\hline 300 & & 0,00 \\
\hline 450 & & 0,00 \\
\hline
\end{tabular}

The volume flow rate of the process at a temperature of $300^{\circ} \mathrm{C}$ ranged from 20000 to $150000 \mathrm{~h}^{-1}$. According the data of Table 3 maximum values of conversion of CO (99-100\%) at $80000-120000 \mathrm{~h}^{-1}$. In general, we took for the optimum the volume flow rate of $80000-100000 \mathrm{~h}^{-1}$.
Table 3: CO conversion on platinum-cobalt catalyst at various volumetric flow rates at $350^{\circ} \mathrm{C}$

\begin{tabular}{|c|c|c|c|}
\hline $\begin{array}{l}\text { Volume flow } \\
\text { rate, } \mathrm{h}^{-1}\end{array}$ & $\begin{array}{c}\text { CO content in exhau } \\
\text { before catalyst }\end{array}$ & $\begin{array}{l}\text { ust gases, ppm } \\
\text { after catalyst }\end{array}$ & Conversion, \% \\
\hline \multicolumn{4}{|l|}{20000} \\
\hline 0,036 & 0,035 & 94 & \\
\hline 50000 & & 0,011 & 97 \\
\hline 80000 & & 0,005 & 99 \\
\hline 100000 & & 0,00 & 100 \\
\hline 120000 & & 0,005 & 100 \\
\hline 150000 & & 0,007 & 98 \\
\hline
\end{tabular}

Three most active catalysts with Co content of 10,15 н $20 \%$ were tested in a pilot plant in the process of oxidation of carbon monoxide in exhaust gases. Data on oxidation of carbon monoxide for these 3 samples of metal block catalysts are presented in Table 4.

Studies were conducted in the temperature range of $50-250^{\circ} \mathrm{C}$ and volume flow rate of $10000 \mathrm{~h}^{-1}$. The process does not proceed at all at $50^{\circ} \mathrm{C}$ and the content of carbon monoxide (in $\mathrm{mg} / \mathrm{m}^{3}$ ) remains unchanged. With temperature increase, the conversion of carbon monoxide increases from $8.7 \%$ and at $250^{\circ} \mathrm{C}$ reaches $100 \%$, i.e. CO is removed completely. When comparing the efficiency of the used catalysts, it is possible to distinguish $20 \%$ Co- $0.5 \% \quad \mathrm{Pt} / \mathrm{Al}_{2} \mathrm{O}_{3}$ (Table 4). Carbon monoxide is almost completely oxidized to $\mathrm{CO}_{2}$ at $250^{\circ} \mathrm{C}$, the content of which increases from 9 to 9.3 vol.\%.

Thus, according to the results of pilot tests, a more than 5-fold decrease of the concentration of carbon monoxide was obtained in the neutralization process at temperatures close to the exhaust gas temperatures on the vehicle, on which measures of the composition of gases was carried out.

Table 4: Oxidation of carbon monoxide on 3 samples of catalysts on a pilot plant

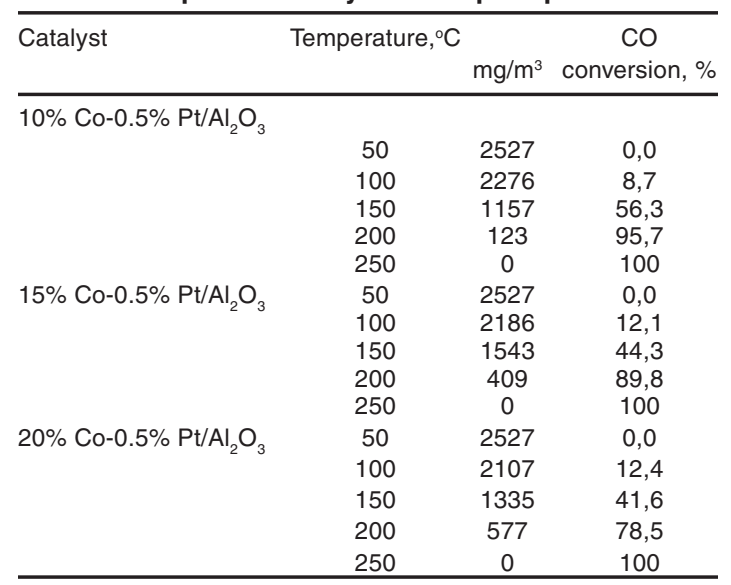


Thermoprogrammed reduction (TPR) of the platinum-cobalt catalyst samples has been carried out in order to study their activity. This gives information about the forms of oxygen that are active in the process of $\mathrm{CO}$ oxidation.

In the work $^{18}$ it was established by XRD method that $\mathrm{CoAl}_{2} \mathrm{O}_{4}, \mathrm{Co}_{3} \mathrm{O}_{4}, \mathrm{Co}$ and $\mathrm{Al}_{2} \mathrm{O}_{3}$ phases are present in $\mathrm{Co} / \mathrm{Al}_{2} \mathrm{O}_{3}$. It was shown that the spinel $\mathrm{CoAl}_{2} \mathrm{O}_{4}$ is low active in the oxidation of $\mathrm{CO}$ and the most active are cobalt oxides.

TPR spectra of $10 \%$ Co/ $/ \mathrm{Al}_{2} \mathrm{O}_{3}$ catalyst calcined at different temperatures of $25-650^{\circ} \mathrm{C}$ are presented in Fig. 5. Heating was carried out in a linear mode up to $1200^{\circ} \mathrm{C}$ and subsequent thermostating at this temperature until the curve completely left on the zero line. Conventionally, the spectrum can be divided into 3 areas: $I$ - up to $550^{\circ} \mathrm{C}$, II $-550-900^{\circ} \mathrm{C}, \mathrm{III}$ - above $900^{\circ} \mathrm{C}$.

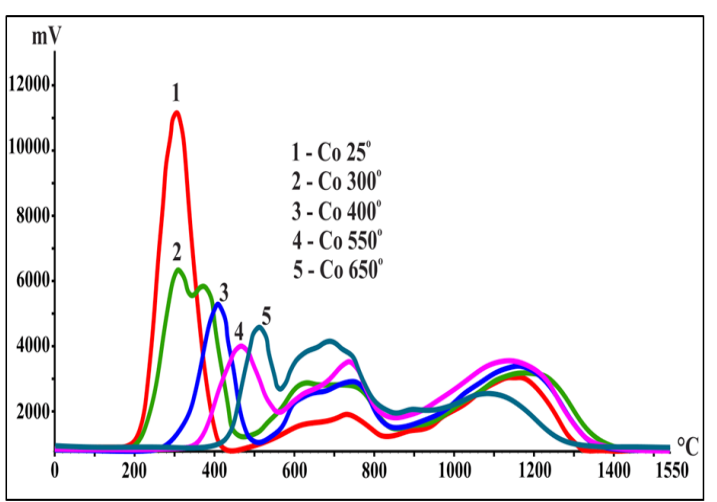

Fig. 5. TPR data for $10 \% \mathrm{Co} / \mathrm{Al}_{2} \mathrm{O}_{3}$, calcined in air at $25-650^{\circ} \mathrm{C}$

In I area of the TPR, the most active oxygen of cobalt oxides obtained in the decomposition process with a linear increase in temperature is reduced by hydrogen. Oxygen of these oxides is the most active in $\mathrm{CO}$ oxidation reactions. As the temperature rises, the oxygen content drops in II area till 0 at $800-850^{\circ} \mathrm{C}$ and the temperature of maximum of oxygen reduction shifts in this area from 350 to $550^{\circ} \mathrm{C}$. In II area, the oxygen peaks are more blurred, their total amount (square of peaks) changes little up to $750^{\circ} \mathrm{C}$, then begins to fall and decreases strongly at $950-1100^{\circ} \mathrm{C}$. In III area, the amount of oxygen in range of $750-800^{\circ} \mathrm{C}$ varies slightly and at $950-1100^{\circ} \mathrm{C}$ almost reaches its maximum. The peak of oxygen of this area corresponds, according to data of XRD to spinel - cobalt aluminate.
The presence of spinel $\mathrm{CoAl}_{2} \mathrm{O}_{4}$ is shown by XRD data. The diffractogram of samples of $10 \% \mathrm{Co} /$ $\mathrm{Al}_{2} \mathrm{O}_{3}$ catalysts (Fig. 6) shows clear intense reflexes typical for $\mathrm{Co}_{3} \mathrm{O}_{4}$ (ASTM 73-1701). It should be noted that $\mathrm{CoAl}_{2} \mathrm{O}_{4}$ spinel (ASTM-3-896) possesses a close set of reflexes. Only the reflex at 4.6558 , which is characteristic for two of them only for $\mathrm{CO}_{3} \mathrm{O}_{4}$, distinguishes both of these compounds: $4.67,2.86$, $2.44,2.02,1.55$ and 1.43 .

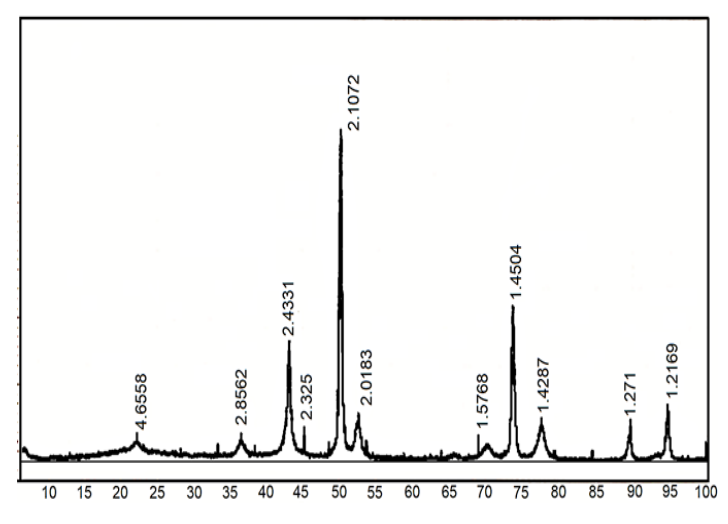

Fig. 6. XRD data of $10 \% \mathrm{Co} / \mathrm{Al}_{2} \mathrm{O}_{3}$

The curves of TPR of $10 \%$ Co $+0.5 \%$ $\mathrm{Pt} / \mathrm{Al}_{2} \mathrm{O}_{3}$ catalysts are presented in Fig. 7. In all three conditional areas there is a shift in temperature ranges associated with the presence of platinum, which can additionally activate hydrogen in the gas mixture of TPR. Perhaps, there is a spillover process of hydrogen activated by platinum. Probably, platinum contributes to the preservation of cobalt in the form of catalytically active oxides, rather than the formation of low-active alumino-cobalt spinel.

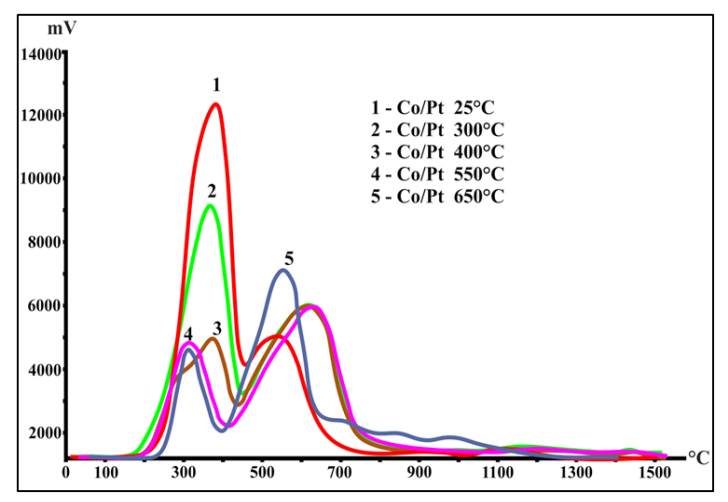

Fig. 7. TPR data for $10 \% \mathrm{Co}+0.5 \% \mathrm{Pt} / \mathrm{Al}_{2} \mathrm{O}_{3}$ calcined in air at $25-1100^{\circ} \mathrm{C}$

Thus according to the TPR data, the oxygen of spinel $\mathrm{CoAl}_{2} \mathrm{O}_{4}$ is the least active in the reaction with hydrogen. Platinum at temperatures up to 
$650^{\circ} \mathrm{C}$ contributes to the preservation of the active cobalt oxides and prevents the formation of cobalt aluminate.

\section{CONCLUSION}

In the process of hydrodearomatization of gasoline fractions of LLP "Atyrau Refinery", it was shown that on the bimetallic catalyst $0.2 \% \mathrm{Rh}-\mathrm{Pt}$ (8:2) $/ \mathrm{Al}_{2} \mathrm{O}_{3}$ the benzene content at hydrogenation of fraction of the Stable catalysate LG decreased from $3.23 \%$ to $0 \%$, and the amount of aromatic hydrocarbons decreased from $55.12 \%$ to $22.6 \%$. In the case of hydrodearomatization of Straightrun gasoline AVT of LLP "Atyrau Refinery" on the same catalyst and under the same conditions as the Stable catalysate, the benzene is completely removed from $0.37 \%$ to $0 \%$, and the amount of aromatic hydrocarbons decreased from $9.93 \%$ to $5.03 \%$. Apparently, the high activity of the catalyst is due to the uniform distribution of nanoscale particles on the surface of aluminum oxide.
The optimal process parameters has been selected for further pilot tests of cobalt-platinum catalysts based on metal blocks on oxidation of carbon monoxide in a laboratory flow installation. The oxidation of CO with $100 \%$ conversion on metal block catalysts begins already at $100^{\circ} \mathrm{C}$. The optimum volumetric flow rate for the oxidative conversion of $\mathrm{CO}$ is $80000-100000 \mathrm{~h}^{-1}$. Tests on a pilot plant also showed the complete removal of $\mathrm{CO}$ from exhaust gases. According to the results of pilot tests, a more than 5 -fold decrease in concentration of carbon monoxide was obtained at temperatures close to the exhaust gas temperatures. It was shown by TPR method that platinum contributes to the preservation of the active cobalt oxides and prevents the formation of inactive cobalt aluminate.

\section{ACKNOWLEDGMENT}

This work was supported by grant No. BR05236739 of the Ministry of Education and Science of the Republic of Kazakhstan.

\section{REFERENCES}

1. Global change of climate. Kazakhstan: the steps to the Kyoto protocol., Project 70-242 TASIS. Astana, 2006. (In Russ.).

2. Andrusevich, A.; Alge, T.; Klemens, T.; Kozak, 3. Practice of the Compliance Committee of the Aarhus Convention., 2008. 78-98.

3. Galperin, L. B.; Fedorov, A. P.; Maslyansky, G. N. Chem. Technol. Fuels Oils., 1974, 1, 42-49.

4. Abu Bakar, N. H .H.; Bettahar, M. M.; Abu Bakar, M.; Monteverdi, S.; Ismail, J.; Alnot, M. J. Catal., 2009, 265, 63-71.

5. Chen, H.; Yang, H.; Omotoso, O.; Ding, L.; Briker, Y.; Zheng, Y.; Ring, Z. Applied Catal. A, Gen., 2009, 358, 103-109.

6. Hiyoshi, N.; Yamaguchi, A.; Rode, C. V.; Sato, O.; Shirai, A. Catal. Comm., 2009, 10, 1681-1684.

7. Zhao, Y.; Shen, B.; Zhang, W.; Tian, R.; Zhang, Zh.; Gao, J. Fuel., 2008, 87, 2343-2346.

8. Brandão, D. S.; Galvão, R. M.; da Graça, M.; da Rocha, M. C.; Bargiela, P.; Sales, E. A. Catal. Today., 2008, 133-135, 324-330.

9. Vangelis, C.; Bouriazos, A.; Sotiriou, S.; Samorski, M.; Gutsche, B.; Papadogianakis, G. J. Catal., 2010, 274, 21-28.

10. Pushkarev, V.V.; An, K.; Alayoglu, S.; Beaumont, S. K.; Somorjai, G. A. J. Catal., 2012, 292, 64-72.

11. Buluta, S.; Fei, Z.; Siankevich, S.; Zhang, J.; Yan, N.; Dyson, P. J. Catal. Today., 2015, 247, 96-103.

12. Pushkarev, V.V.; An, K.; Alayoglu, S.; Beaumont, S. K.; Somorjai, G. A. J. Catal., 2012, 292, 64-72.

13. Li, T.; Xia, D.; Zhou, G.; Xie, H.; Jiao, Z. Catal.
Comm., 2018, 112, 35-38.

14. Sabbe, M.K.; Canduela-Rodriquez, G.; Reyniers, M-F.; Marin, G. B. J. Catal., 2015, 330, 406-422.

15. Ye, G.;Sun, Y.;Zhou, X.;Zhu, K.;Zhou, J.; Coppens, M-O. Chem. Eng. J., 2017, 329, 56-65.

16. Sanchez, A.;Fang, M.;Ahmed,A.;Sanchez-Delgado, R. A. Applied Catal. A, Gen., 2014, 477, 117-124.

17. Boudjahem, A. G.; Redjel, A.; Mokrane, T. J. Ind. Eng. Chem., 2012, 18, 303-308.

18. Baghbanian, S. M.; Farhang, M.; Vahdat, S. M.; Tajbakhsh, M. J. Mol. Catal. A, Chem., 2015, 407, 128-136.

19. Rattan, G.; Kumar, M. Ahem. Chem. Technol., 2014, 8, 249-260.

20. Cole, K.;Carley, A.;Mandy, C.M.;Clarke, M.;Taylor, H. T.; Hutchings, G. J. Catal. Lett., 2010, 138, 143-147.

21. Wang, H-F.; Kavanagh, R.; Guo, Y. L.; Guo, Y.; Hu, P. J. Catal., 2012, 296, 110-119.

22. Oliveira, H. A.; Franceschini, D. F.; Passos, F. B. J. Brazil. Chem. Soc., 2014, 25, 53-65.

23. Ma, W.; ; Keogh, R. A.; Bukur, D. B.; Davis, B. H. Applied Catal. A, Gen., 2012, 437-438, 1-9.

24. Vosoughi, V.; Dalai, A. K.; Abatzoglou, N.; Hu, Y. Applied Catal. A, Gen., 2017, 547, 155-163

25. Frolova, O. A.; Massenova, A. T.; Sassykova, L. R.; Basheva, Zh. T.; Baytazin. E.; Ussenov. A. Int. J. Chem. Sci., 2014, 12, 625-634.

26. Sassykova, L. R.; Ussenov, A.; Massenova, A. T.; Gil'mundinov S. A.; Rakhmetova, K. S.; Bunin, V. N.; Basheva, Z. T.; Kalykberdiyev, M. K. Int. J. Chem. Sci., 2016, 14, 206-212. 